\title{
DESCRIPTIONS OF THE CALLING AND COURTSHIP SONGS OF TIBICEN ESFANDIARII DLABOLA, 1970 (AUCHENORRHYNCHA: CICADIDAE)
}

\author{
Fariba Mozaffarian $^{1}$ and Allen F. Sanborn ${ }^{2}$ \\ ${ }^{1}$ Insect Taxonomy Research Department, Iranian Research Institute of Plant Protection, \\ Agricultural Research, Education and Extension Organization \\ P.O. Box 1454, 19395 Tehran, Iran \\ E-mail:mozaffarian@iripp.ir, faribamozaffarian@gmail.com, https://orcid.org/0000-0003-0163-7997 \\ ${ }^{2}$ Barry University, Department of Biology, 11300 NE Second Avenue, Miami Shores \\ FL 33161-6695, USA. E-mail: asanborn@barry.edu, https://orcid.org/0000-0001-5729-7106
}

The calling song of Tibicen esfandiarii Dlabola, 1970 is described for the first time. The calling song consists of a continuous train of syllables (3-9 $\mathrm{ms})$ and short intersyllable intervals ( 0.4 to $1.9 \mathrm{~ms})$. The song begins at a lower intensity, increasing intensity through a series of steps to the ultimate portion of the call that is produced for an extended period at this loudest intensity. The song terminates after a short pause $(2 \mathrm{~ms})$ that is followed by about $0.5 \mathrm{~s}$ of singing. The total syllable repetition frequency is $193.1 \pm 60.24 \mathrm{~Hz}$ ( $\mathrm{n}=48$ measurements from six individuals) and the frequency of the average peak energy of calling song is $4875 \pm 59.45 \mathrm{~Hz}$ ( $\mathrm{n}=6$ individuals) and courtship songs ( $\mathrm{n}=15$ parts of call from one individual) is $4875 \pm 0 \mathrm{~Hz}$. The courtship song consists of alternative phrases usually starting after a short pause (average of $70.8 \pm 4.85 \mathrm{~ms}$ ) and syllable frequency reducing from the average of 157.0 $\pm 7.1 \mathrm{~Hz}$ to $128.4 \pm 1.67 \mathrm{~Hz}$. The duration, frequency of syllables and the average RMS amplitude in different portions of the song and in different specimens are measured and the behavior of the specimen during song production is described. We show significant differences in the frequency and temporal components of T. esfandiarii from its congeneric species, Tibicen plebejus (Scopoli, 1763), with which is shares part of its range in Iran.

Key words: calling song, courtship song, Tibicen esfandiarii.

\section{INTRODUCTION}

Tibicen esfandiarii Dlabola, 1970 is a large, endemic cicada of southern Iran (Mozaffarian \& SANborn 2010, 2016). Although the largest of the Iranian cicadas, little is known about the biology of the species. Dlabola (1970) provided no information on the biology of the species with the description of the species and AваII (2000) reported the species as a pest on Quercus spp., but most references to the species are in the listing of it as part of a broader study (Nast 1972, Mirzayans et al. 1976, Dlabola 1981, Mirzayans 1995). Distributional data showed the species only inhabits southern Iran and is found at altitudes between 210-2291 m above sea level and the species was reported to emerge in large densities in some years (MozAffarian \& SANBorn 2016). Information on the species call is currently lacking. 
A detailed study (Mozaffarian \& Sanborn 2016) of the morphology and distribution of T. esfandiarii and T. plebejus (Scopoli, 1763) inhabiting Iran showed that although the two species are very similar morphologically and there is some overlap in the extremes ranges of color and morphometric characters of the two species, there are highly significant $(p<0.0001)$ differences in the morphometric traits and distributions of the two species. The calling songs of cicadas are known to be species specific and analysis of the song would provide additional data to distinguish the species in Iran as well as basic information about T. esfandiarii. This study is a description and analysis of the calling and courtship songs of T. esfandiarii. We provide comparative analysis to T. plebejus from Iran in order to facilitate distinguishing the two Iranian species.

We have retained the usage of Tibicen Latreille, 1825 as the valid genus throughout the paper. There is currently a proposal under consideration by the International Commission of Zoological Nomenclature to determine whether Tibicen or Lyristes Horváth, 1926 should be used for members of the genus (Boulard \& Puissant 2014, Marshall \& Hill 2014, Sanborn 2014, Marshall 2015, Puissant et al. 2015). There is currently no decision by the Commission.

\section{MATERIAL AND METHODS}

The calling and courtship songs of T. esfandiarii were recorded in Khabr National Park and villages in the region of the park in Kerman province, Iran in 2013 and Kavar, Fars province, Iran in 2017. Songs were recorded with a Zoom Handy Recorder H4 at a sampling rate of $96 \mathrm{KHz}$ and 24-bit resolution, microphones with $\pm 3 \mathrm{db}$ sensitivity up to 11-12 kHz whereupon the frequency response decreases. In 2013 (in Kerman province) the microphones were located closer than twice of the body length of the specimens. Therefore, the recordings were not included in the statistical analyses provided here due to the potential near field effect based on the proximity of the microphone recording. In 2017 (in Fars province), the microphones were located in the far field approximately $100 \mathrm{~cm}$ from the calling individuals and a total of $10 \mathrm{~min}$ and $1.569 \mathrm{~s}$ of the calling songs of 6 specimens and $6 \mathrm{~min}$ and $56.544 \mathrm{~s}$ of the courtship song of one specimen were recorded. Notes on the behavior of the cicadas during singing were also made. The recorded song files were analyzed using Adobe Audition CS6 Version 5.0, the durations of different portions of the songs, syllables and intersyllable intervals, pauses, the frequency of syllables in any individual and in different portions of the songs, the average peak call energy (frequency of maximum intensity) and the average RMS amplitude in different parts of the song were calculated. Sections of the call with minimum background noise were selected and scanned in order to calculate the amplitude for an individual song segment. No filters or other sound manipulating programs were used when recording or analyzing the calls. The collected specimens were deposited in Hayk Mirzayans Insect Museum, Tehran, Iran (HMIM). We apply standard bioacoustics terminology to the description of the songs. The song is produced as phrases are repeated for extended periods of time. Each phrase is composed of a series of repeating syllables, the time between syllables is the intersyllable interval. Individual syllables are produced by the buckling of the timbal and timbal ribs. 
Student $t$-tests were performed using InStat 3 for the Macintosh (Graphpad Software, San Diego) to compare acoustic parameters of the two species of Tibicen.

\section{RESULTS}

Location, time and vegetation - The calling song of T. esfandiarii was recorded from 6 specimens calling from Amygdalus sp. for a total of $18 \mathrm{~min}$ and 5.025 $\mathrm{s}$ in Kavar, $29^{\circ} 3.911^{\prime} \mathrm{N} 52^{\circ} 38.494^{\prime} \mathrm{E}, 1755 \mathrm{~m}$, Fars province, 26 July 2017. Recording began at about 11:00 AM with the final call being recorded prior to the termination of the calling period at about 14:00 PM, in Firouzabad, Khergheh as well, close to the collecting site. Singing T. esfandiarii specimens were observed in Kerman province during July 2013 on Juglans sp. and Prunus sp.

Calling behavior and male density - In both localities, the cicadas were singing with their head upward with the body axis aligned along the trunks and branches of the trees. Intraspecific competition while calling significantly influences escape behavior in T. esfandiarii. After a mass emergence in Kerman province during 2013, several specimens were observed singing from the same tree. Their sensitivity to environmental threats was very low and they could be collected easily by hand a few days after the mass emergence began to decline. However, during the much lower density Fars province emergence in 2017, single male specimens were observed singing on any tree and they flew away when they heard any small noise while being approached.

Calling song - The calling song of T. esfandiarii is a continuous steady buzz without any wing clicks. The beginning of a song bout was recorded in two specimens, one in 2017 and one in 2013 (Figs 1a,b). The calling song started with a train of syllables with short intersyllable intervals increasing to maximum amplitude in only a few steps. At the beginning, the average relative RMS amplitude was equal to $-31.4 \mathrm{~dB}$ for $2 \mathrm{~s}$. The RMS amplitude increased to $-19.78 \mathrm{~dB}$ for $4 \mathrm{~s}$, the song continued with the average RMS amplitude of $-15.44 \mathrm{~dB}$ for $7 \mathrm{~s}$ and finally continued with an average relative RMS amplitude of $-11.44 \mathrm{~dB}$ for the remainder of the calling bout (Fig. 1a). A similar song pattern was recorded in 2013 from this species in Kerman province (Fig. 1b) illustrating consistency in song pattern over the geographic range of the species.

Detailed analysis of the audio files showed the calling song is a continuous train of syllables with lower amplitude oscillations at the end and short intersyllable intervals between them (Figs $2 a-e$ ). Every syllable consisted of two higher amplitude parts followed by lower amplitude oscillations to the pulse terminus (Figs $2 a-c$ ). The syllables are separated by intersyllable intervals of 0.4 to $1.9 \mathrm{~ms}$ (average $1.36 \pm 0.45, \mathrm{n}=42$ measurments in 5 individuals). In the higher amplitude portions of the song (Figs $2 c-e$ ), the amplitude of the terminal parts of both sections of the syllable and intersyllable interval increased (Figs $2 c-d$ ) and intersyllable intervals in some cases became rather 
unclear (Fig. 2e). The duration of intersyllables were decreased as the song amplitude increased. Intersyllable duration was determined to be $0.7-1.9 \mathrm{~ms}$ (average $1.53 \pm 0.36 \mathrm{~ms}, \mathrm{n}=32$ measurements in 3 individuals) in lower amplitude portions of the call (as in Figs $2 a-b$ ), and $0.4-1.05 \mathrm{~ms}$ (average $0.8 \pm 0.19$ $\mathrm{ms}, \mathrm{n}=10$ measurements in 2 individuals) for higher amplitude portions of the call (as in Figs $2 c-e$ ). The change in amplitude during call initiation is illustrated with the following example. The range of average relative RMS amplitude in syllables with recognizable parts (Figs $2 a-b$ ) was measured between -17.67 to $-12.02 \mathrm{~dB}$ with an average of $-13.66 \pm 1.70 \mathrm{~dB}(\mathrm{n}=17$ measurements in 3 individuals). The range of average relative RMS amplitude within syllables as shown in Figs $2 c-e$ was -12.55 to $-7.54 \mathrm{~dB}$ with an average of $-9.83 \pm 1.68 \mathrm{~dB}$ ( $\mathrm{n}=10$ measurements in 3 individuals). The range of syllable duration was 3 to $9 \mathrm{~ms}$ in all song segments but the average varied slightly from $4.56 \pm 1.59 \mathrm{~ms}$ ( $\mathrm{n}=16$ measuremens) for Figs $2 a-b$ to $3.11 \pm 1.17 \mathrm{~ms}$ ( $\mathrm{n}=9$ measurements) for the louder portions of the call (Figs $2 c-e$ ).

Syllable frequencies showed less variation within than between individuals but was sometimes reduced in short periods in the same individual (Fig. 4).

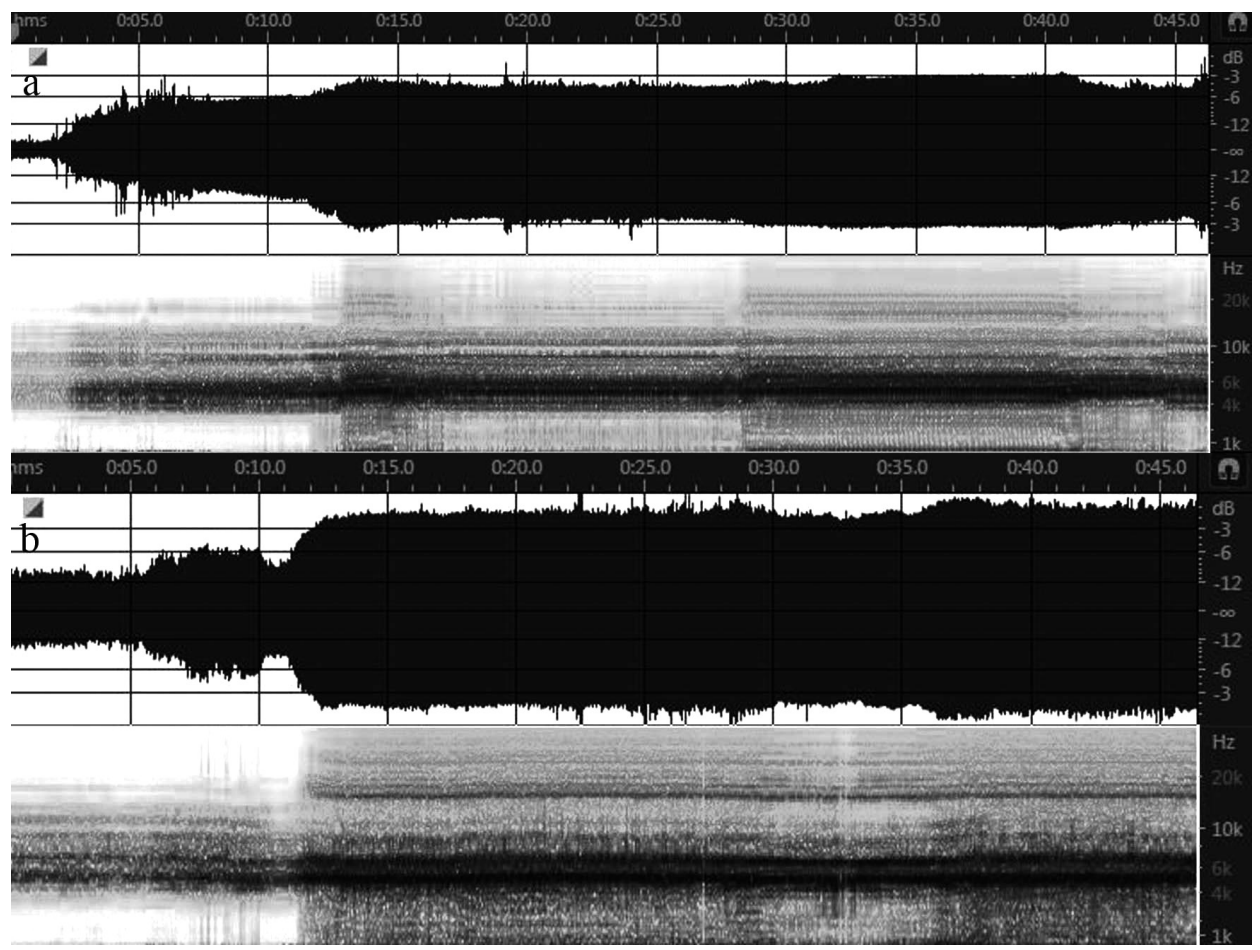

Fig. 1. Initiation of a calling song of T. esfandiarii: $a=$ Kavar (Fars province, July 2017), $b=a$ similar song recorded in Godar-e Sabz (Kerman province, July, 2013) 


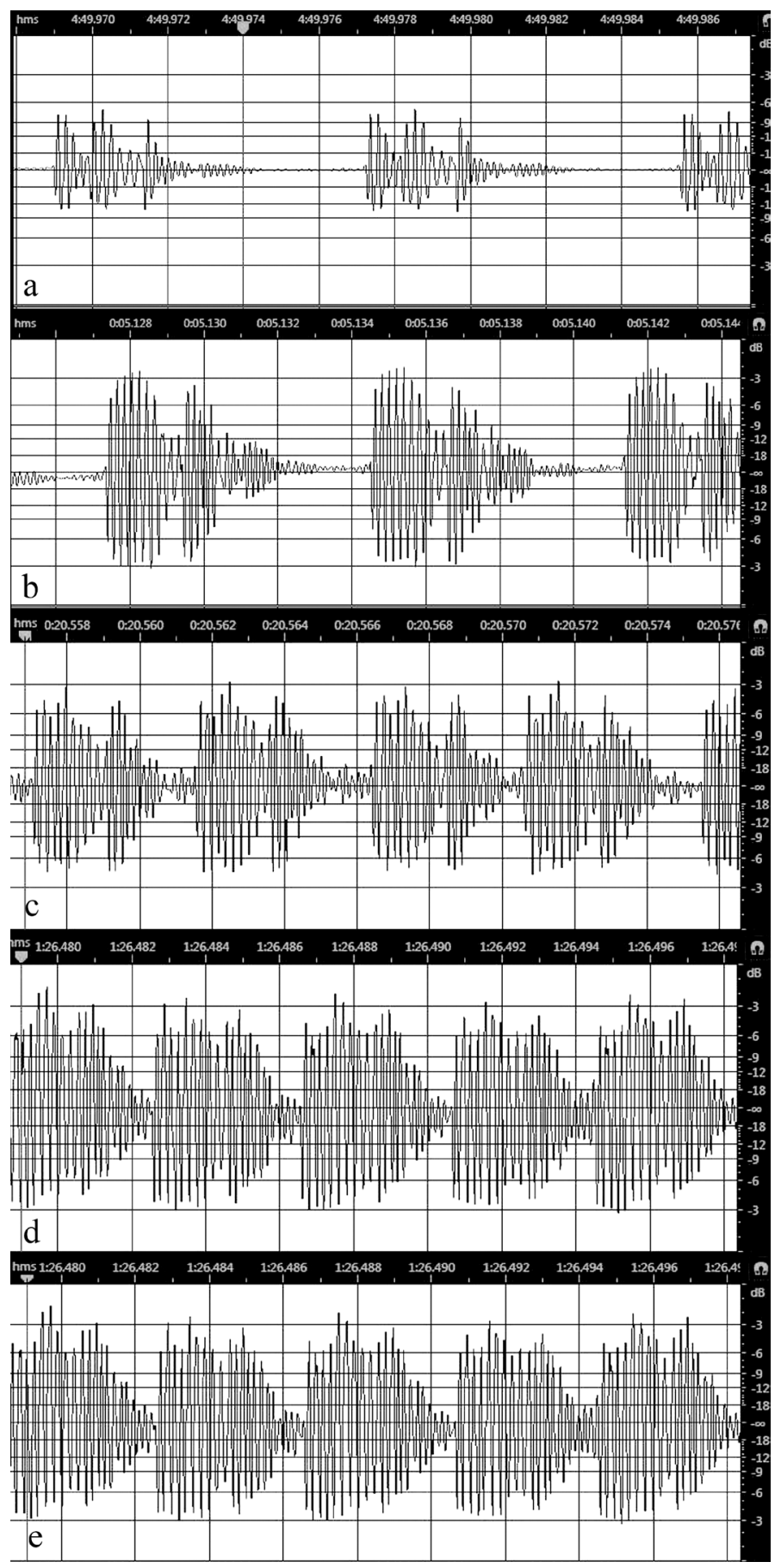

Fig. 2. Variation in the shapes of syllables by increasing the average RMS amplitude in any portion of the calling (a, c, d, e) and courtship song (b) of T. esfandiarii: $\mathrm{a}=-20.00$ $\mathrm{dB}, \mathrm{b}=-11.23 \mathrm{~dB}, \mathrm{c}=$ $-10.95 \mathrm{~dB}, \mathrm{~d}=-9.01$ $\mathrm{dB}, \mathrm{e}=-8.20 \mathrm{~dB}$ (Fars province, Kavar, July 2017). Time is indicated on the upper margin of each image 
The individual variation of syllable frequency (with total recording time) was determined to be: specimen no. 1 (4.747 s): $146 \pm 0 \mathrm{~Hz}$ ( $\mathrm{n}=3$ measurements); specimen no. 2 (10 min and $15.031 \mathrm{~s}$ ): $135 \mathrm{~Hz}$ to $147 \mathrm{~Hz}$, but after $17 \mathrm{~s}$, the frequency reduced to $106 \mathrm{~Hz}$ to $110 \mathrm{~Hz}$, the average for all syllables being $137.37 \pm 12.43 \mathrm{~Hz}(\mathrm{n}=30$ measurements); specimen no. 3 (4 min and $20.224 \mathrm{~s})$ : $191 \mathrm{~Hz}$ to $293 \mathrm{~Hz}$, the average $232.6 \pm 33.54 \mathrm{~Hz}$ ( $\mathrm{n}=7$ measurements); specimen no. 4 (4 min and $23.026 \mathrm{~s}$ ): $198 \mathrm{~Hz}$ to $325 \mathrm{~Hz}$, the average $256.4 \pm 44.64 \mathrm{~Hz}$ $(\mathrm{n}=8$ measurements). In specimens no. 5 (30.5 s) and no. 6 ( $2 \mathrm{~min}$ and $28 \mathrm{~s})$, the interval oscillations grew and pulses could not be recognized easily for counting. The total syllable frequency average was calculated as $193.1 \pm 60.24$ $\mathrm{Hz}$ (specimens no. 1 to 4 ). Within a single specimen, there was an increase in amplitude along with the increasing syllable frequency. However, comparing different specimens, a more intense song was not correlated with an increasing syllable frequency. The average peak call frequency in the 6 specimens was $4875 \pm 59.45 \mathrm{~Hz}$ (range of $4781-4969 \mathrm{~Hz}$ ).

Calling song termination was recorded only in one specimen. The song paused for $2 \mathrm{~ms}$ prior to song termination phrase. The frequency of the sound syllables was consistent at $260 \mathrm{~Hz} 0.1 \mathrm{~s}$ before and after the pause. After the short pause, the song continued for $453 \mathrm{~ms}$ and then terminated.

Courtship song - While recording the calling song of one specimen, a female flew in near the calling male and sat on a branch of the same tree (Fig. 4). As soon as the female arrived, the continuous rhythm of the calling song shifted to an alternative courtship song composed of similar phrases (Fig. 5). The courtship song was recorded for $6 \mathrm{~min}$ and $56.544 \mathrm{~s}$. Initially, the song paused for $113 \mathrm{~ms}$. The pause altered the frequency of syllables, reducing it from $147 \mathrm{~Hz}$ to $129 \mathrm{~Hz}$. In the next second, the syllable frequency returned

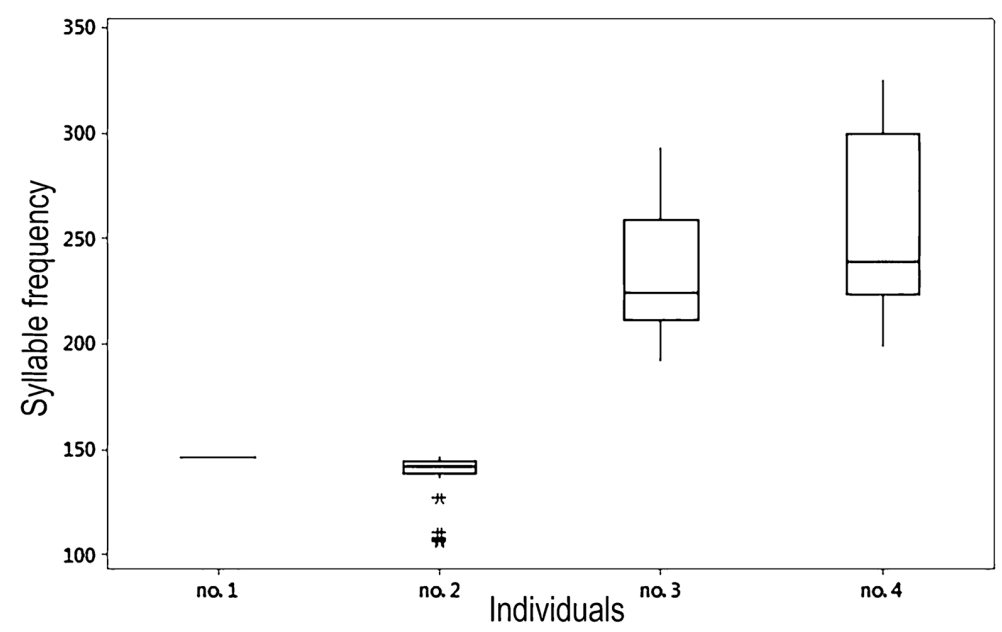

Fig. 3. Variation of syllable frequencies among the songs of 4 specimens 


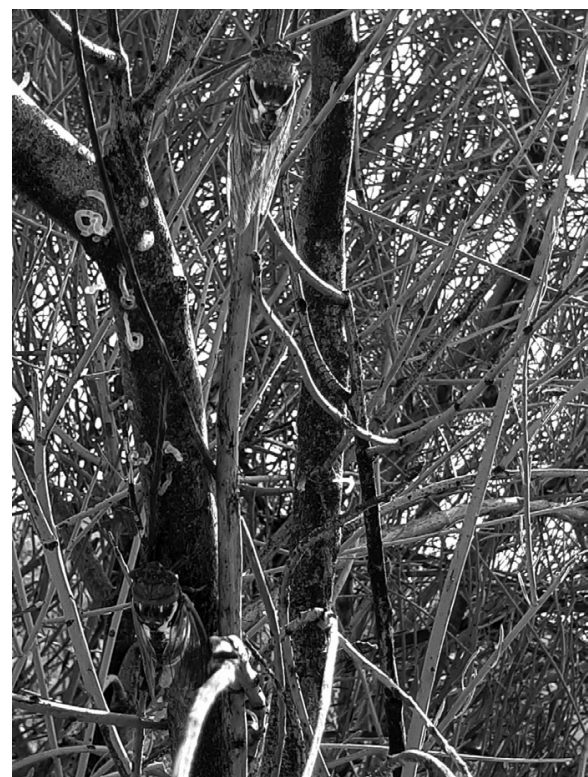

Fig. 4. A calling male T. esfandiarii (bottom) with a female (top) on the tree (Amygdalus sp.) in Kavar (Fars province, July 2017) to $149 \mathrm{~Hz}$ and then the syllable frequency reduced gradually over $6 \mathrm{~s}$ to $128 \mathrm{~Hz}$. The reduction of syllable frequency was accompanied by a reduction of syllable amplitude. This courtship call was repeated as different phrases (from one pause to the next pause) as long as the female remained on the tree. The pattern of one of the courtship phrases is shown in Fig. 6 . The two first phrases consisted of 5 cycles of alternative increasing and decreasing intensity before reaching the next pause at the beginning of the next phrase. However, in the following phrases, the intensity was reduced gradually towards the end of the phrase, sometimes with small short increases in intensity during the reduction in intensity. The duration of the pause at the beginning of the first courtship phrase (113 ms) was longer than the pauses at the beginning of the following phrases. The pause was reduced in the next phrases but it could be recognized at the beginning of all courtship phrases with the minimum of $64 \mathrm{~ms}$ and a maximum of $78 \mathrm{~ms}$ with an average of $70.6 \pm 4.85 \mathrm{~ms}$. The average of the maximum and minimum syllable frequencies in phrases was calculated as $157.0 \pm 7.04 \mathrm{~Hz}$ ( $\mathrm{n}=5$ mea-

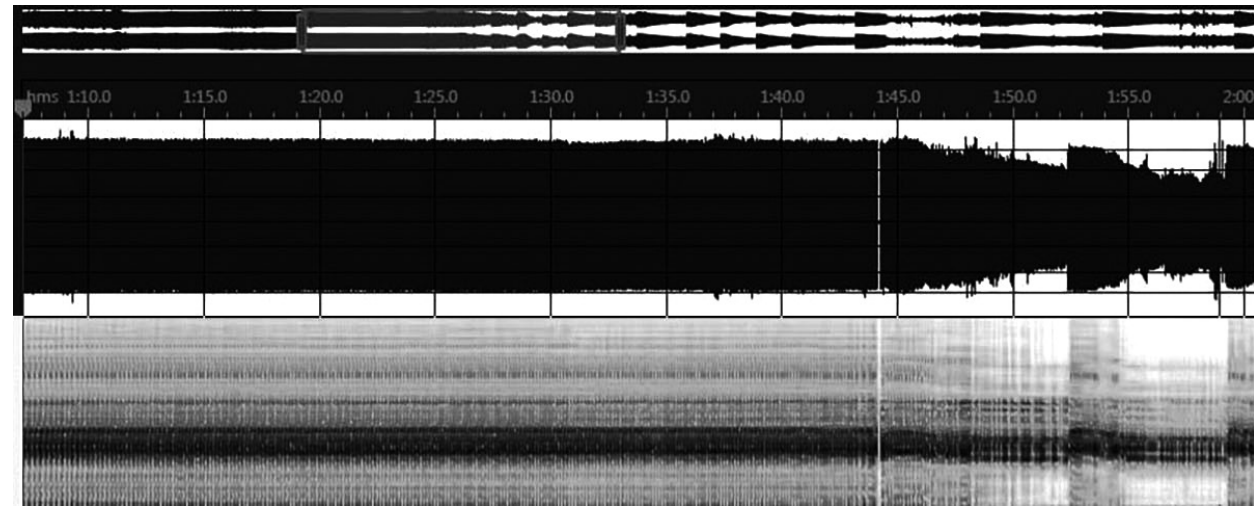

Fig. 5. Change from the calling song rhythm to the courtship call rhythm in a calling male with the arrival of a female T. esfandiarii 
surements) and $128.4 \pm 1.67 \mathrm{~Hz}$ ( $\mathrm{n}=5$ measurements) respectively. The average peak sound energy frequency in all courtship phrases did not vary and was equal to $4875 \pm 0 \mathrm{~Hz}$ ( $\mathrm{n}=15$ measurements in one individual). The duration of the courtship phrases ranged from $15.3 \mathrm{~s}$ to $47.4 \mathrm{~s}$ with an average of $28.7 \pm 7.99$ $\mathrm{s}(\mathrm{n}=13$ measurements). The first phrase lasted $33.4 \mathrm{~s}$ and the second phrase lasted $47.4 \mathrm{~s}$, each phrase consisting of 5 cycles. The range and the average of the cycle durations increased in the second phrases: In the first phrase, cycle durations ranged from 5.5 to $8.1 \mathrm{~s}$ with an average of $6.7 \pm 1.06 \mathrm{~s}(\mathrm{n}=5$ measurements). In the second phrase, the cycle durations ranged from 8.2 to $11.9 \mathrm{~s}$ with an average of $9.5 \pm 1.47 \mathrm{~s}(\mathrm{n}=5$ measurements). The following phrases lacked the obvious cycles of increasing and decreasing intensity. The duration for the third phrase was $15.3 \mathrm{~s}$ and increased rather irregularly to $36.9 \mathrm{~s}$ in the

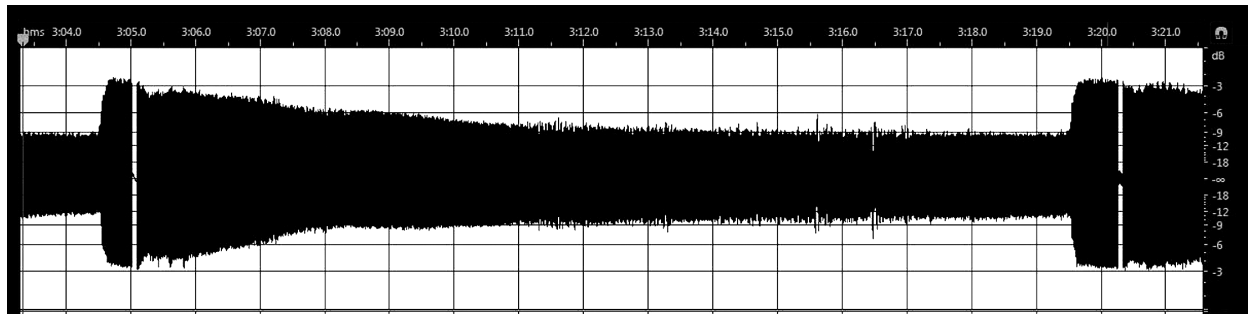

Fig. 6. An expansion of a courtship song phrase of a male T. esfandiarii in the presence of a female on the same tree

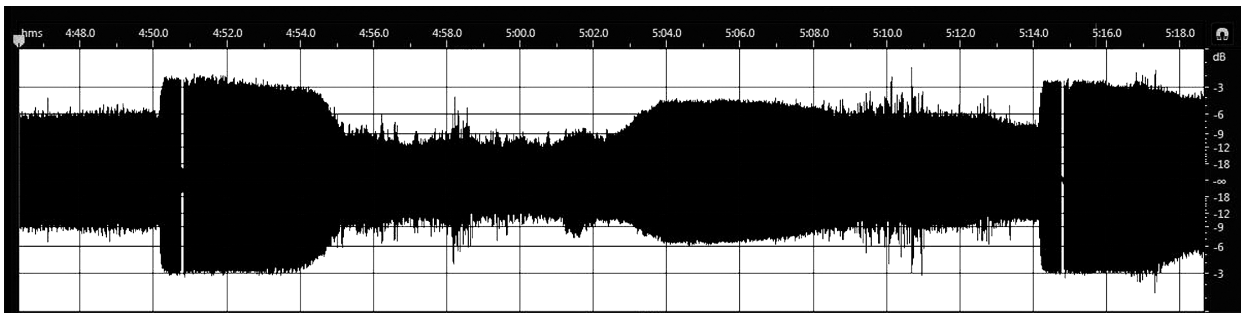

Fig. 7. Changing pattern of the courtship song cycles with prolonged courtship song production in a male T. esfandiarii in the presence of a female on the same tree

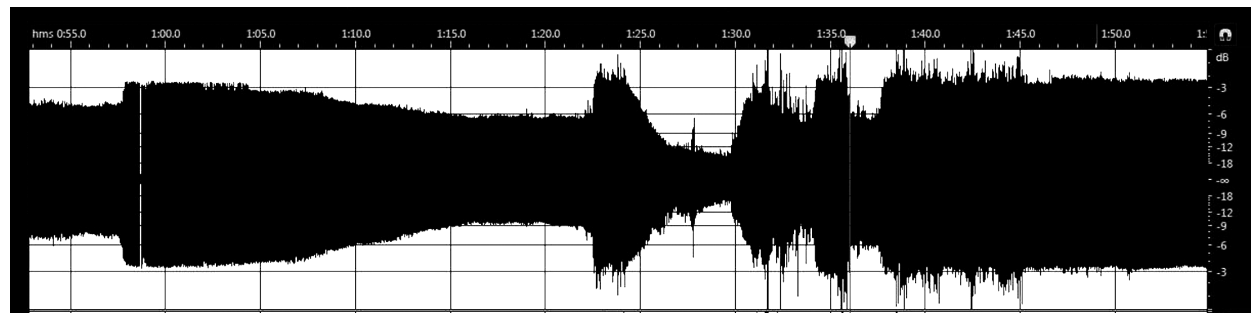

Fig. 8. Return of song pattern from the courtship song to the calling song by a male T. esfandiarii after the female being courted flew away. The red line locates the short pause (55 $\mathrm{ms}$ ) after female departed prior to resuming the calling song 
last phrase. The duration of syllables within the phrases was 6 to $9 \mathrm{~ms}$ as it was in the calling song. The duration of syllables increased as the amplitude of the phrase decreased. In the second minute of the male singing the courtship call in the presence of female, the duration of the phrases reached $31 \mathrm{~s}$ and while the syllable frequency and amplitude were reducing both syllable frequency and amplitude twice increased temporarily (Fig. 7) as the male moved slowly toward the female. The male extended his wings and the tip of his abdomen moved outward as the amplitude of the song increased. In the last phrase, the duration reached $38 \mathrm{~s}$, temporarily increasing amplitude and syllable frequency three times as the male movements towards the female were repeated but the female flew away. As soon as the female departed, a short pause $(55 \mathrm{~ms})$ appeared in the male song, the syllable frequency reduced from $146 \mathrm{~Hz}$ to $133 \mathrm{~Hz}$, then increased to $142 \mathrm{~Hz}$ as the song continued with the earlier continuous rhythm of the calling song (Fig. 8).

Comparison to T. plebejus song - The temporal pattern, syllable duration, and intersyllable intervals of T. esfandiarii and T. plebejus within Iran can be compared to T. plebejus using the data of Medhipour et al. (2015). The calling song of T. esfandiarii differs from the calling song previously described for $T$. plebejus in the temporal pattern (constant with phrases lasting for periods of minutes vs. amplitude modulated with phrases lasting for $12.19 \pm 3.63 \mathrm{~s}, \mathrm{n}=17$ calls), syllable duration ( $3.11 \pm 1.17 \mathrm{~ms}, \mathrm{n}=9$ vs. $54.57 \pm 7.53, \mathrm{n}=17, \mathrm{t}=20.182$, d.f. $=24, \mathrm{p}<0.0001)$, syllable frequency $(193.1 \pm 60.24 \mathrm{~Hz}, \mathrm{n}=48$ vs. $12.24 \pm 0.89$, $\mathrm{n}=17, \mathrm{t}=12.314$, d.f. $=63, \mathrm{p}<0.0001)$ and intersyllable interval $(1.36 \pm 0.45 \mathrm{~ms}, \mathrm{n}$ $=42$ vs. $25.82 \pm 9.83, \mathrm{n}=17, \mathrm{t}=16.294$, d.f. $=57, \mathrm{p}<0.0001)$ (Medhipour et al. 2015).

\section{DISCUSSION}

The song of T. esfandiarii is a relatively simple call when compared to many cicada calls. There are some initial modifications to increase intensity at the beginning of a call bout but is constant in its parameters after the song reaches maximum intensity. Cicada song frequency is determined by the resonant frequency of the timbal organ (Pringle 1954, Bennet-Clark 1995). The peak frequency of the T. esfandiarii song determined here is less than $50 \mathrm{~Hz}$ from the predicted value $(4828 \mathrm{~Hz})$ and well within the $95 \%$ confidence interval of the relationship between body size and call frequency determined by Bennet-Clark and Young (1994).

Each syllable is composed of two large components. This may represent the individual sound pulses from the two timbals so that the timbals may be activated at slightly different times. It appears as if the timbals are operating slightly out of phase (Fig. 2). Further experimentation would be necessary to confirm this hypothesis (e.g. Aidley 1969, Young \& Josephison 1983a, b, FonSECA 1996, SANBORN 2001). 
The call of T. plebejus has been described multiple times (e.g., Popov 1971, 1975, 1985, Lodos \& Boulard 1987, Boulard 1988, Quartau \& Rebelo 1994, Boulard 1995, Boulard \& Mondon 1996, Gogala 1998, Boulard 2000, Gogala 2002, Sueur et al. 2004, Boulard 2006) with Joermann and Schneider (1987) providing the most detailed temporal and frequency component analysis. The calling song of Iranian specimens was described by MeHdipour et al. (2015). The song of T. plebejus begins with a short buzz followed by a long period of amplitude modulations produced as the abdomen is alternately raised and lowered rather than the continuous constant amplitude call found in the calling song of T. esfandiarii. The peak frequency of Iranian T. plebejus calls is around $6.1 \mathrm{kHz}$ (Mehdipour et al. 2015) which is due to the smaller size (MoZAFFARIAN \& SANBORN 2016) and the relationship of size to resonant frequency in cicadas (Bennet-Clark \& Young 1994).

The calling song of T. esfandiarii differs significantly from the calling song previously described for T. plebejus (Medhipour et al. 2015). The differences in the song parameters of the two species represent further evidence along with the morphology and biogeography (Mozaffarian \& SANborn 2016) that the species are distinct.

The observations provided here increase the number of potential host species for T. esfandiarii. The species had been associated previously only with Quercus spp. (АваI 2000). The species was observed calling from Amygdalus sp., Juglans sp., and Prunus sp. here so that a greater variety of host plants may exist or the species will call from a variety of sites that have some other characteristic the males find beneficial for calling. Oviposition of the females in these new plant associations will be necessary to determine if they represent potential host plants or are simply calling sites.

Acknowledgement - The authors sincerely thank the Iranian Department of Environment for providing permission to collect specimens and record songs in conservation areas and national parks in Kerman and Fars provinces. Special thanks to Ata Sahafii and Yousef Shahimoridi of that organization for accompanying and supplying the first author with the information on collecting sites in Khabr National Park. Two anonymous reviewers made suggestions that improved the manuscript.

\section{REFERENCES}

АваII, M. (2000): Pests of forest trees \& shrubs of Iran. - Ministry of Agriculture, Agricultural Research, Education \& Extension Organization, Tehran, $178 \mathrm{pp}$.

Aidley, D. J. (1969): Sound production in a Brazilian cicada. - Journal of Experimental Biology 51: 325-337.

BenNeT-Clark, H. C. (1995): Insect sound production: Transduction mechanisms and impedance matching. - Symposia of the Society for Experimental Biology 49: 383-409. 
Bennet-Clark, H. C. \& Young, D. (1994): The scaling of song frequencies in cicadas. - Journal of Experimental Biology 191: 291-294.

Boulard, M. (1988): Les Lyristes d'Asie Mineure (Hom. Cicadidae). I. Sur deux formes éthospécifiques syntopiques et description de deux espèces nouvelles. - L'Entomologiste 44: 153-167.

Boulard, M. (1995): Postures de cymbalisation, cymbalisations et cartes d'identité acoustique des cigales. 1. Généralités et espèces méditerranéennes (Homoptera Cicadoidea). - Ecole Practique des Hautes Etudes, Travaux du Laboratoire Biologie et Evolution des Insectes Hemipteroidea 7-8: 1-72.

Boulard, M. (2000): Espèce, milieu et comportement. - Ecole Pratique des Hautes Etudes, Travaux du Laboratoire Biologie et Evolution des Insectes Hemipteroidea 13: 1-40.

Boulard, M. (2006): Facultés acoustiques, éthologie sonore des cigales, entomophonateurs par excellence. - Ecole Pratique des Hautes Etudes, Travaux du Laboratoire Biologie et Evolution des Insectes Hemipteroidea 16: 1-181.

Boulard, M. \& Mondon, B. (1996): Vies et mémoires de cigales. - Equinoxe, Barbentane, 159 pp.

Boulard, M., \& Puissant, S. (2014): Comments on Tibicina Amyot, 1847 and Lyristes Horváth, 1926 (Insecta, Hemiptera, Homoptera): proposed conservation by the suppression of Tibicen Berthold, 1827 (Case 239). - Bulletin of Zoological Nomenclature 71: 119-131. https://doi.org/10.5962/bhl.part.910

Dlabola, J. (1970): Beiträge zur Taxonomie und Chorologie einiger palaearktischer Zikadenarten (Homoptera, Auchenorrhyncha). - Mitteilungen der Münchner Entomologischen Gesellschaft 59: 90-107.

Dlabola, J. (1981): Ergebnisse der Tschechoslowakisch-Iranischen Entomologischen Expedition nach dem Iran (1970-1973). - Acta Entomologica Musei Nationalis Pragae 40: 127-308.

FonsECA, P. J. (1996): Sound production in cicadas: Timbal muscle activity during calling song and protest song. - Bioacoustics 7: 13-31. https://doi.org/10.1080/09524622.1996.9753312.

Gogala, M. (1998): The songs of cicadas of Slovenia. - Proteus 60: 392-399.

Gogala, M. (2002): Gesänge der Singzikaden aus Südost- und Mittel-Europa. - Denisia 4: 241-248.

Joermann, G. \& Schneider, H. (1987): The songs of four species of cicada in Yugoslavia (Homoptera: Cicadidae). - Zoologischer Anzeiger 219: 283-296.

Lodos, N. \& Boulard, M. (1987): Bazi Cicadidae (Homoptera: Auchenorrhyncha) türlerinin taninmalarinda sesin taksonomik karakter olarak kullanilmasi üzerinde bir araştirma. - Türkiye I. Entomoloji Kongresi, 13-16 Ekim 1987, Izmir, Bildirileri, Entomoloji Derneği Yayınları 3: 643-648.

Marshall, D. C. (2015): Comments on Tibicina Amyot, 1847 and Lyristes Horváth, 1926 (Insecta, Hemiptera, Homoptera): proposed conservation by the suppression of Tibicen Berthold, 1827 [?Latreille, 1825], and concerning the type species of Cicada Linnaeus, 1758. - Bulletin of Zoological Nomenclature 72: 217-219. https://doi.org/10.5962/bhl.part.910

Marshall, D. C. \& Hill, K. B. R. (2014): Comments on Tibicina Amyot, 1847 and Lyristes Horváth, 1926 (Insecta, Hemiptera, Homoptera): proposed conservation by the suppression of Tibicen Berthold, 1827 (Case 239). - Bulletin of Zoological Nomenclature 71: 103-107. https://doi.org/10.5962/bhl.part.910

Mehdipour, M., Sendi, J. \& Zamanian, H. (2015): External morphology and calling song characteristics in Tibicen plebejus (Hemiptera: Cicadidae). - Comptes Rendus Biologiqes 338: 103-111. https://doi.org/10.1016/j.crvi.2014.10.008

Mirzayans, H. (1995): Insects of Iran. The list of Homoptera: Auchenorrhyncha in the insect collection of Plant Pests \& Diseases Research Institute. - Plant Pests \& Diseases Research Institute, Insects Taxonomy Research Department Publication Number 1. 59 pp. 
Mirzayans, H., Hashemi, A., Borumand, H., Zairi, M. \& Rajabi, G. H. (1976): Insect fauna from Province of Fars (Iran) (1). - Journal of Entomological Society of Iran 3: 109-135.

Mozaffarian, F. \& Sanborn, A. F. (2010): The cicadas of Iran with the description of two new species (Hemiptera, Cicadidae). - Mitteilungen aus dem Museum für Naturkunde im Berlin, Deutsche Entomologische Zeitschrift 57: 69-84. https://doi.org/10.1002/ mmnd.201000006

Mozaffarian, F. \& Sanborn, A. F. (2016): Two species of the genus Tibicen Latreille, 1825 (Hemiptera: Cicadidae) in Iran, with an identification key to the genera of the family Cicadidae (Hemiptera) in the country. - Acta Zoologica Bulgarica 68: 469-476.

Nast, J. (1972): Palearctic Auchenorrhyncha (Homoptera): An annotated checklist. - Polish Scientific Publishers, Warszawa, 550 pp.

Popov, A. V. (1971): Synaptic transformation in the auditory system of insects. Pp. 301-320. In: Gersuni, G. V. (ed.): Sensory processes at the neuronal and behavioural level. - Academic Press, New York. https://doi.org/10.1016/b978-0-12-281350-4.50022-2

Popov, A. V. (1975): The structure of the tymbals and the characteristics of the sound signals in singing cicadas (Homoptera, Cicadidae) in the southern regions of the USSR. - Entomological Review, Washington 54: 7-35.

Popov, A. V. (1985): Akusticheskoe povedenie i slukh nasekomykh (Acoustic behavior and hearing of insects). - Nauka, Leningrad, 253 pp. [In Russian]

Pringle, J. W. S. (1954): A physiological analysis of cicada song. - Journal of Experimental Biology 31: 525-560.

Puissant, S., Boulard, M., Lee, Y. J., Hayashi, M., Wei, C. \& Sueur, J. (2015): Comments on Tibicina Amyot, 1847 and Lyristes Horváth, 1926 (Insecta, Hemiptera, Homoptera): proposed conservation by the suppression of Tibicen Berthold, 1827 [?Latreille, 1825], and concerning the type species of Cicada Linnaeus, 1758. - Bulletin of Zoological Nomenclature 72: 219-220. https://doi.org/10.5962/bhl.part.910

Quartau, J. A. \& Rebelo, M. T. (1994): Sinais acústicos em Cicadidae e Cicadellidae (Homoptera, Auchenorryncha) que ocorrem em Portugal. - Actas do I Congresso Nacional de Etologia, Lisboa 1994: 137-142.

SAnborn, A. F. (2001): Timbal muscle physiology in the endothermic cicada Tibicen winnemanna (Homoptera: Cicadidae). - Comparative Biochemistry and Physiology. A. Physiology 130: 9-19. https://doi.org/10.1016/s1095-6433(01)00363-4

SAnborn, A. F. (2014): Comments on Tibicina Amyot, 1847 and Lyristes Horváth, 1926 (Insecta, Hemiptera, Homoptera): proposed conservation by the suppression of Tibicen Berthold, 1827 (Case 239). - Bulletin of Zoological Nomenclature 71: 108-118. https://doi. org/10.5962/bhl.part.910

Sueur, J., Puissant, S., Simoes, P. C., Seabra, S., Boulard, M. \& Quartau, J. A. (2004): Cicadas from Portugal: revised list of species with eco-ethological data (Hemiptera: Cicadidae). - Insect Systematics and Evolution 35: 177-187. https://doi. org/10.1163/187631204788912373

Young, D. \& Josephson, R. K. (1983a): Mechanism of sound-production and muscle contraction kinetics in cicadas. - Journal of Comparative Physiology. A. Sensory, Neural, and Behavioral Physiology 152: 183-195. https://doi.org/10.1007/bf00611183

Young, D. \& Josephson, R. K. (1983b): Pure-tone songs in cicadas with special reference to the genus Magicicada. - Journal of Comparative Physiology. A. Sensory, Neural, and Behavioral Physiology 152: 197-207. https://doi.org/10.1007/bf00611184

Received August 27, 2019, accepted February 20, 2020, published May 15, 2020 